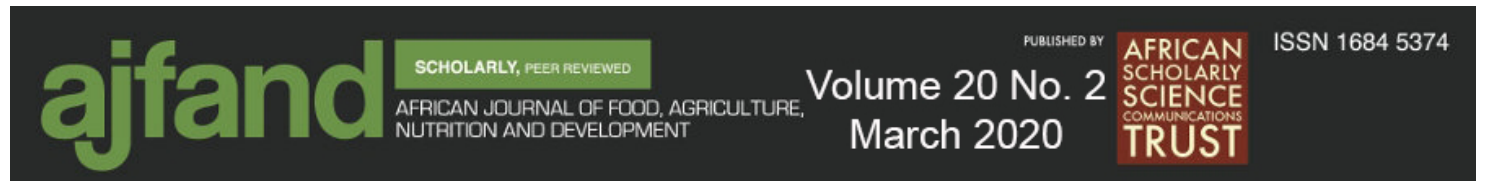

Afr. J. Food Agric. Nutr. Dev. 2020; 20(2): 15523-15537

DOI: 10.18697/ajfand.90.19175

\title{
CONSUMPTION OF DIFFERENT FORMS OF FISH IN ABAKALIKI \\ METROPOLIS OF EBONYI STATE, NIGERIA
}

\section{Onyeneke RU ${ }^{1 *}$, Amadi MU1, Iheanacho SC ${ }^{2}$, Uwazie UI $^{3}$ and MO Enyoghasim ${ }^{4}$}

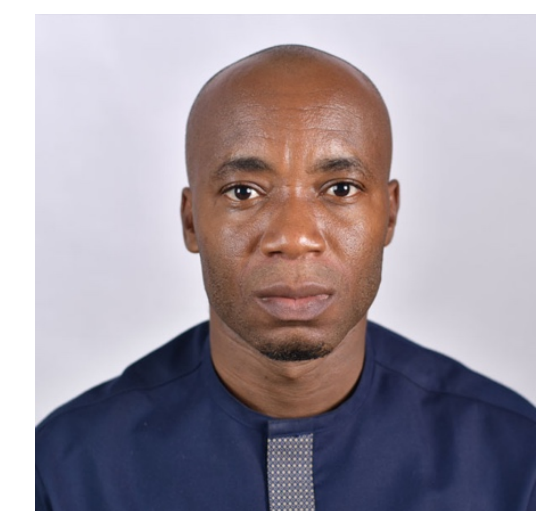

Robert Ugochukwu Onyeneke

*Corresponding author email: robertonyeneke@yahoo.com , robert.onyeneke@,funai.edu.ng

${ }^{1}$ Department of Agriculture (Agricultural Economics and Extension Programme)

Alex Ekwueme Federal University Ndufu-Alike, Ebonyi State, Nigeria

${ }^{2}$ Department of Fisheries and Aquaculture, Alex Ekwueme Federal University NdufuAlike, Ebonyi State, Nigeria

${ }^{3}$ Department of Economics, Michael Okpara University of Agriculture Umudike, Nigeria

${ }^{4}$ Department of Economics and Development Studies, Alex Ekwueme Federal University Ndufu-Alike, Ebonyi State, Nigeria 


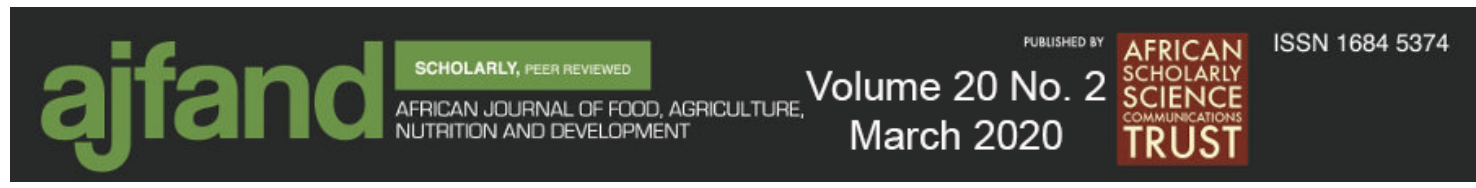

\begin{abstract}
Fish represents an important component of protein intake of many households in Nigeria. The different forms of fish available for consumption in most urban areas of Nigeria are fresh, smoked, dried or frozen fish. Households have different preferences for different forms of fish arising from changes in demand, price and income of the household. This creates the need to study and understand the level of demand for the different forms of fish consumed, the factors that influence fish consumption and how the demand for different forms responds to changes in price and income of consumers. It is in recognition of this fact that the present study assessed the demand for different forms of fish in Abakaliki metropolis of Ebonyi State, Nigeria. The paper describes the socio-economic characteristics of the fish consumers in Abakaliki metropolis, estimated the quantity and price of different forms of fish consumed in Abakaliki metropolis, ascertained the determinants of consumption of different forms of fish in the area and computed the income and price elasticities of fish demand in the area. Fifty-four (54) consumers were randomly selected from the area and interviewed using a structured questionnaire. Using descriptive statistics, seemingly unrelated regression analysis, income and price elasticities, the study found that the largest number of the consumers $(75.9 \%)$ was interested in fresh fish. Dried fish was the second most preferred fish form consumed by the households $(72.2 \%)$ while frozen fish emerged was consumed by $64.8 \%$ of the households making it the third preferred fish form in the area. The least preferred form of fish consumed in the area was smoked fish and 53.7\% of the households consumed this fish form. The average monthly demand was highest for frozen fish. Furthermore, the findings show that age, household size, income, price of different forms of fish, education and gender were significant predictors of fish consumption. All the different forms of fish were price and income inelastic, with varying levels of inelasticity.
\end{abstract}

Key words: Fish, Consumption, Income, Price, Elasticity, Seemingly unrelated regression 


\section{INTRODUCTION}

Fish is as an important component of a modern healthy diet and also a critical food source for developing countries [1]. Fish provides key macro- and micro-nutrients, protein and are low in saturated fat [2]. Fish consumption has been linked to a wide array of health benefits for infants and adults including the developing foetus [3]. According to Nesheim and Taktine [4], fish can supply up to 50 percent or more of high quality protein, mineral elements (zinc, magnesium, iron, copper and potassium), vitamins ( $\mathrm{B}_{6}, \mathrm{~B}_{12}$, niacin, thiamine, riboflavin, vitamin E) and essential fatty acids such as oleic acid and omega3 fatty acid. The United Nations Food and Agriculture Organization (FAO) [5]) noted that world population growth has outweighed fish production due to increased fish consumption. Fish consumption per capita across the world has increased from $9.0 \mathrm{~kg}$ in the 1961 to $20.5 \mathrm{~kg}$ in 2017 [5].

Considering the upsurge in population growth, urbanisation and demographic dynamics $[6,7]$, fish consumption (demand) raises enormous challenges for economies. Utilization of fish varies for food and non-food purposes across countries and regions. More importantly, the utilization of fish for direct human consumption increased significantly over the years from 67 percent in 1960 to 88 percent in 2016 [8]. Hence, the consumption patterns for fish have peculiar implications for the sub-sector in various economies. Disparities exist for fish consumption between and within countries, regions and areas due to location specific varieties, per capita consumption quantity, geographic concentration of production and more importantly, the trade and international trade realities [9]. Currently, people are more enlightened with the growing awareness creation on the nutritional and health value of fish food supplies, contributing to the upsurge in disproportionate demand for fish [10]. In the past, there were indications that fish products were a relatively cheaper source of animal protein [11]. That notwithstanding, what are the assertions in recent times considering the demand-supply dynamics, demographics, preferences and status of fish production in the country? Fresh, dried and smoked fish appear to be common forms of fish consumed by Nigerians [12].

Consumption of fish also depends on the interplay of demand and supply factors. On the demand side are the factors of income, population growth and prices, whereas the supply side is relative to the fish production method and the cost of production. Vannuccini et al. [8] and Alexandratos and Bruinsma [13] posit the vital importance of income and prices to fish consumption especially in low and middle income countries, bearing in mind that the underlying assumption for demand also involves the trends of food mix preferences. Abakaliki is an emerging city in Nigeria with varying demand for different forms of fish given the increasing population of its inhabitants. Fish, a major source of protein, represents a crucial component of the diet of consumers in developing economies, whose diets are heavy in staples [10]. There is, therefore, the need to understand the level of demand for the different forms of fish consumed, the factors that influence fish consumption and how the demand for different forms respond to changes in price and income of consumers. Better understanding of these aspects will help shape policies and programmes, thus enhancing the development of fish enterprises and business in the State. 


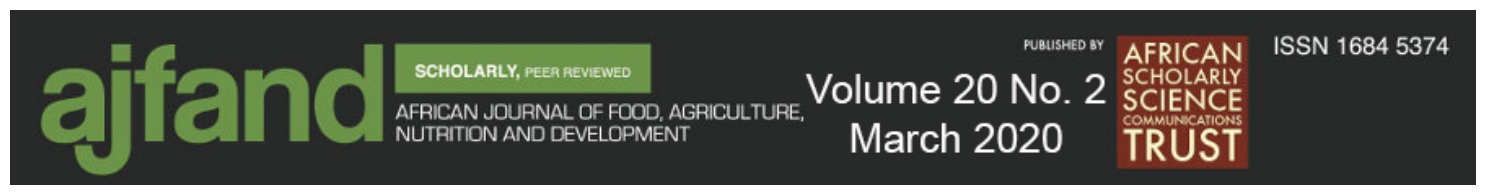

\section{METHODOLOGY}

The study was conducted in Abakaliki metropolis of Ebonyi State, Nigeria. Abakaliki is the capital city of Ebonyi State. We sampled a total of fifty-four fish consumers from the area and used a structured questionnaire with three sections to gather data from the fish consumers. Section one consisted of questions on socioeconomic characteristics of fish consumers; section two considered questions on the different forms of fish consumed in the area, the price, demand and expenditure on the different forms of fish consumed; while section three elicited information on the constraints to fish consumption in the area.

The study used statistical and quantitative analysis to analyse the data collected. Descriptive statistics (such as frequency distribution, mean and percentage), income and price elasticities and seemingly unrelated regression (SUR) analysis were employed in analysing the data. The SUR model for this study is specified as follows:

$$
\begin{gathered}
y_{a i}=\sum_{j=1}^{k i} x_{a i j} \beta_{i j}+\varepsilon_{a i}, a=1,2, \ldots, A ; i=1,2, \ldots, I ; j \\
=1,2, \ldots, k_{i}
\end{gathered}
$$

Where;

$y_{a i}=$ the $\mathrm{a}^{\text {th }}$ observation on the $\mathrm{i}^{\text {th }}$ dependent variable (quantity of fish consumed measured in $\mathrm{kg}$ ) explained by the $\mathrm{i}^{\text {th }}$ regression equation.

$\mathrm{x}_{\mathrm{aij}}=\mathrm{a}^{\text {th }}$ observation on $\mathrm{j}^{\text {th }}$ exogenous variable in the $\mathrm{i}^{\text {th }}$ equation.

$\beta \mathrm{ij}=$ parameter estimate of $\mathrm{x}_{\mathrm{aij}}$.

$\varepsilon a i=$ the error term associated with the $i^{\text {th }}$ equation of the model.

Objective 4 was achieved using income and own price elasticities formulae. The formula for own price elasticity used in this study is written below:

$e_{p}=\left(\frac{d Q}{d P}\right)\left(\frac{P_{a v}}{Q_{a v}}\right)$

2

Where;

$e_{p}=$ Own price elasticity of demand of the form of fish

$\left(\frac{d Q}{d P}\right)$

$=$ Coefficient of own price from the result of the seemingly unrelated regression

$P_{a v}=$ Average price of the form of fish

$Q_{a v}=$ Average monthly demand or consumption of the form of fish

The formula for income elasticity used in this paper is written as:

$e_{I}=\left(\frac{d Q}{d I}\right)\left(\frac{P_{a v}}{Q_{a v}}\right)$ 
Where;

$e_{p}=$ Income elasticity of demand of the form of fish

$\left(\frac{d Q}{d P}\right)$

$=$ Coefficient of income from the result of the seemingly unrelated regression

$P_{I}=$ Average monthly income of the consumers

$Q_{a v}=$ Average monthly demand or consumption of the form of fish

\section{RESULTS AND DISCUSSION}

\section{Socio-economic Characteristics of Consumers}

About $48.1 \%$ of the consumers were males while $51.9 \%$ were females (Table 1), representing an adult population averaging 30 years old. This reflects respondents who are persons of reasonable age, rational and able to understand the market-consumer interactions relative to the forms of fish. Most respondents $(88.1 \%)$ had tertiary level of education. Table 1 also shows that $48.1 \%$ of the respondents were single and $51.9 \%$ married. The average household size of the consumers was 4 persons. This category of persons was appropriate for elucidating the realities of fish consumption market, since specific demand for animal-protein such as fish maybe considered only as a 'crop of opportunity' and not a necessity for the rural dwellers. The status is also one of not "below the poverty line" population as the average income of the respondents was \$61740.70 (\$171.50), which was above the \$2/day poverty mark-up.

\section{Quantity and Price of Different Forms of Fish Consumed}

The demand and price range of the different forms of fish consumed is shown in Table 2. While the largest number of the consumers $(75.9 \%)$ was interested in fresh fish compared to the other forms, the average monthly demand was highest for frozen fish. This may be related to its utility, affordability and availability in a form widely preferred by the consumers (going by the principles of demand). Further, we observed that fresh fish which usually includes fresh catfish and croaker fish had the lowest average monthly demand. This is not unrelated to the occasional consumption of this form of fish as it is mostly marketed in places of relaxation, entertainment or social gatherings, and is also more expensive than the other forms. The result is in line with the findings of Alhassan et al. [14] in Tamale Metropolis of Ghana, where they found frozen/fresh fish type to be more preferred than smoked fish. It indicates that the demand and consumption outcomes for different forms of fish are place specific [15] and also depend on the relative preferences/attributes of the consumers.

\section{Determinants of Consumption of Different forms of Fish}

The results of the regression for the determinants of the demand for the different forms of fish are shown in Table 3. The Chi square likelihood ratio test for all the forms of fish is significant, meaning that the independent variables included in the regression are relevant to the outcome variable.

For fresh fish demand, income of the consumer, gender, price of fresh fish and price of dried fish are the significant predictors. The findings revealed that the level of income of the consumer, gender, and the price of dried fish are all positively related to the demand 


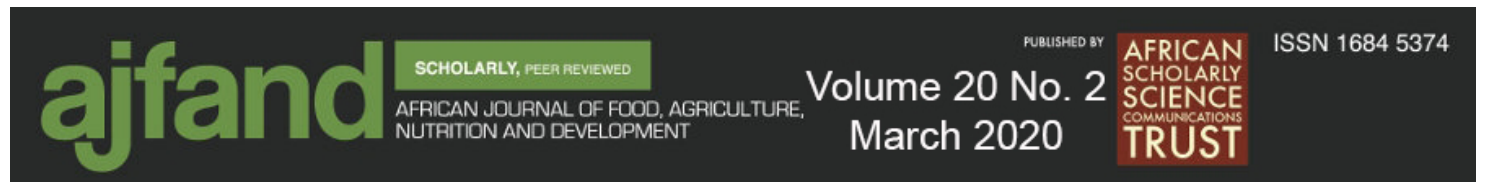

for fresh fish. This means that the higher the income and expenditure levels, the higher the demand for the fresh fish. Also demand for fresh fish increased with price of dried fish. This implies that fresh fish and dried fish are substitutes. On the other hand, price of fresh fish as expected was negatively related to its demand.

Ordinarily, demand is influenced by price or affordability but in addition, other factors of availability and consumer preferences and taste are validly important for demand [16]. However, the fish consumption behaviour and its associated social factors have strong implications for the demand in different places [17]. This is the case with fresh fish consumption in Nigeria. Availability of fresh fish is less in the hinterland and more in the coastal regions, while the production (rearing) of fresh fish is limited by species survivability and the cost of production. This creates a supply gap in locations where fresh fish cannot be easily harvested from the wild. Hence, fresh fish is more expensive and usually afforded by higher income earners. That notwithstanding, the association between demand for fresh fish and price is still a priori correct as shown by its relationship with its own price because of the close substitutability offered by the other forms of fish.

Also, age, household size, income, education, price of fresh fish and price of dried fish were significant determinants of demand for dried fish. The age of the consumer was a negative and significant predictor of demand for dried fish. Also, price of dried fish was negative and significant predictor of its demand. Income, education, household size and the price of fresh fish had positive effects on the demand for dried fish.

The determinants of dried fish demand are similar to those of fresh fish. Dried fish in this region is in the form of 'stock fish' locally known as okporoko, which is mostly a completely dried with no moisture content (usually imported). There is also the other locally processed form of dried fish, dried in kilns to negligible moisture content levels. This process is usually done to save the cost of fish, preserve the shelf-life of the fish and also facilitate movement of fish food over long distances to various locations. Dried fish demand, therefore shares various characteristics with those of the fresh fish. In fact, we can say that dried fish form is more like a "low-budget fresh fish" with the added utility of form and place, which enhances its availability. Hence, it is priced relatively lower than fresh fish. The age of the consumer showed an inverse relationship to demand for dried fish. This supports the idea that the younger age groups consume more fish than that consumed by the older age groups [18]. This could be related to the awareness of healthy life benefits of protein-dense foods and particularly of white meat as that for fish.

The age of the consumer significantly decreased demand for smoked fish in the area, while household size significantly increased the demands for dried fish and smoked fish. The price of smoked fish was a significant determinant of smoked fish demand, while the price of frozen fish significantly increased its consumption. This may also be connected to the role frozen fish plays in the preparation of the smoked fish, since smoked fish is mostly 'de-frozen' fish which the retailers have no other means or intention to continue preserving as frozen fish. This simply implies that frozen fish in essence does not specifically serve as a means to an end in terms of smoked fish; rather; 


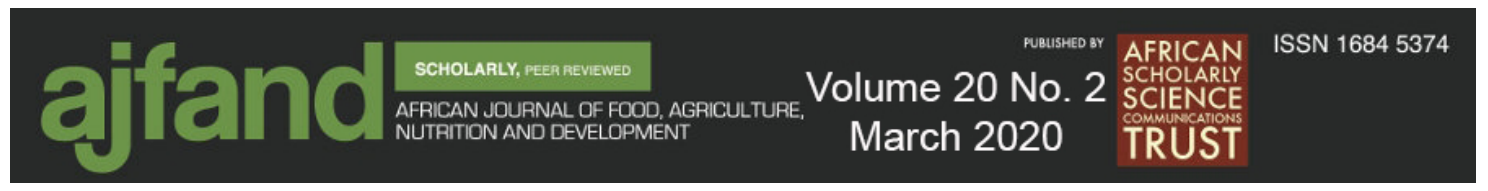

smoked fish is usually a product of the limited storage facilities of the suppliers. It does not, however, take away the comparative desirability of frozen fish by most consumers.

The study found positive relationship between education and demand for dried fish. This outcome is in line with various literature $[18,19,20]$, which found a significant association between education and the consumption of fish. There are, however, other studies which similarly found no association between education and fish consumption $[21,22]$. The income of consumers and its related variable of total budget for fish showed strong positive relationship to demand for fish, contrary to the sign on the income variable for fish consumption by Burger et al. [19] in their USA study. Other known studies which corroborated the positive relationships for the income and household size variable against demand for fish include Amao et al. [11], Can et al. [18] and Dalhatu and Ala [22].

\section{Price and Income Elasticities of Demand for Different Forms of Fish}

Table 4 shows that the price elasticity of fresh and dried fish were inelastic (less than one in absolute terms) with the usual negative sign. Dried fish had the highest magnitude of price elasticity of demand. Frozen and smoked fish had a positive sign for its own-price elasticity of demand. This means that a unit increase in the price of frozen fish increased its demand (even though the magnitude is small). The income elasticity of frozen fish and smoked fish, although positive as in a normal good, was small in magnitude. All four types of fish had positive but low income elasticities.

The overall positive income in-elasticities shown by the different forms of fish in this study are similar to the findings of Debnath et al. [23] in urban Tripura where the income elasticity of demand for all the choice fish groups investigated were positive and inelastic. In their study in Bangladesh, Dey et al. [24] disaggregated the income and price elasticity of demand for the different types of fish studied into income quartile levels of the consumers. Generally, income elasticity was positive and elastic for categories of 'high-valued' fish types but inelastic for others; however, the fourth quartile (highest income) group recorded negative income elasticity for a fish type known as 'assorted small fish'. In their study, own-price elasticity also had a similar pattern; all negative as expected but elastic only for the groups of 'high-valued' fish types. Similarly, our finding is related to the result of Nankwenya et al. [25], who found increased budget share for dried fish and fresh fish than for smoked fish. They also found that fresh fish and dried fish had higher own-price elasticities than smoked fish.

\section{CONCLUSION}

Fresh fish is the highest priced form of fish in the consumer market, whereas smoked fish is the lowest priced. As the income of the consumers increases, they buy only a little more smoked and frozen fish because most smoked fish consumed in the Metropolis are perceived to be of low quality. Wealthier consumers tend to buy more of fresh fish and dried fish (such as stock fish), which consumers perceive to be of better quality in terms of nutrition and safety. The dried and fresh forms of fish are substitutes mainly because the most common type of fresh fish in the area (the catfish) is also the dried fish in the market. The socio-economic characteristics of the respondents reveal that the consumers 


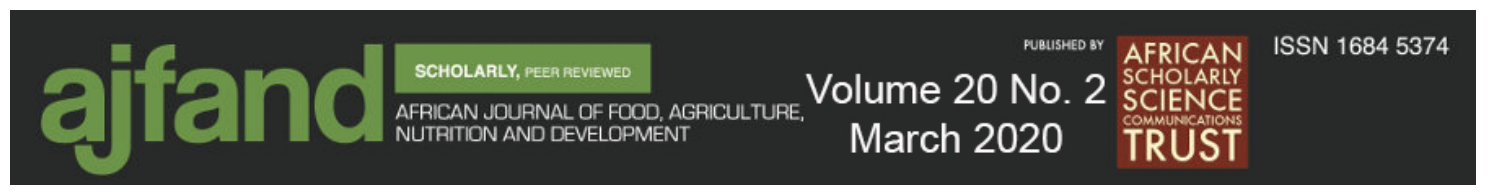

are not poor. These categories of the population are mostly educated and well exposed and are well within their regular in-take of fish protein. However, there is need for further research to disaggregate the consumption groups and account for the required fish protein in-take levels in the study area. The consumption and demand pattern for fish in the study area implies that the food fish market needs to be more developed in terms of value addition to this primary-product, which is prone to demand inelasticity. There is also a viable market for the fresh fish form given the right pricing. Efficient allocations of resources for its production will thus, reduce cost, improve supply, drive-down the market price and increase the choice alternatives of the consumers. The study recommends the improvement of the market for fish by creating value through packaging, processing and better storage facilities. This can be achieved by government provision of steady power supply and agro-processing industries which must be linked to production. 


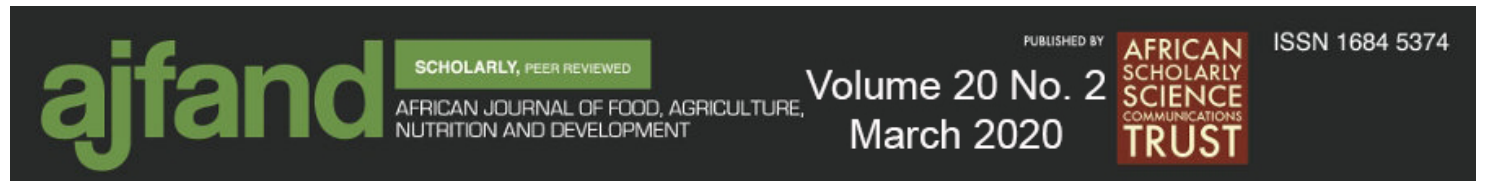

Table 1: Distribution of fish consumers' socioeconomic characteristics

\begin{tabular}{|c|c|c|c|}
\hline $\begin{array}{l}\text { Socioeconomic } \\
\text { characteristic }\end{array}$ & Frequency & Percentage & Average \\
\hline \multicolumn{4}{|l|}{ Gender } \\
\hline Male & 26 & 48.1 & \\
\hline Female & 28 & 51.9 & \\
\hline Total & 54 & 100.0 & \\
\hline Age (years) & & & 29.9 years \\
\hline $18-27$ & 22 & 40.7 & \\
\hline $28-37$ & 23 & 42.6 & \\
\hline $38-47$ & 7 & 14.8 & \\
\hline $48-57$ & 1 & 1.9 & \\
\hline Total & 54 & 100.0 & \\
\hline \multicolumn{4}{|l|}{ Marital status } \\
\hline Married & 28 & 51.9 & \\
\hline Single & 26 & 48.1 & \\
\hline \multicolumn{4}{|l|}{$\begin{array}{l}\text { Household size } \\
\text { (number of } \\
\text { persons) }\end{array}$} \\
\hline $1-5$ & 43 & 79.6 & \\
\hline $6-10$ & 8 & 14.8 & 4 persons \\
\hline $11-15$ & 3 & 5.6 & \\
\hline Total & 54 & 100.0 & \\
\hline \multicolumn{4}{|l|}{ Educational level } \\
\hline Primary & 3 & 5.6 & \\
\hline Secondary & 3 & 5.6 & \\
\hline Tertiary & 48 & 88.9 & \\
\hline Total & 54 & 100.0 & \\
\hline \multicolumn{4}{|l|}{ Income (\#) } \\
\hline $1-60,000$ & 35 & 64.8 & $¥ 61,740.7$ \\
\hline $60,001-120,000$ & 15 & 27.8 & \\
\hline $120,001-180,000$ & 1 & 1.9 & \\
\hline $180,001-240,000$ & 3 & 5.6 & \\
\hline Total & 54 & 100.0 & \\
\hline
\end{tabular}




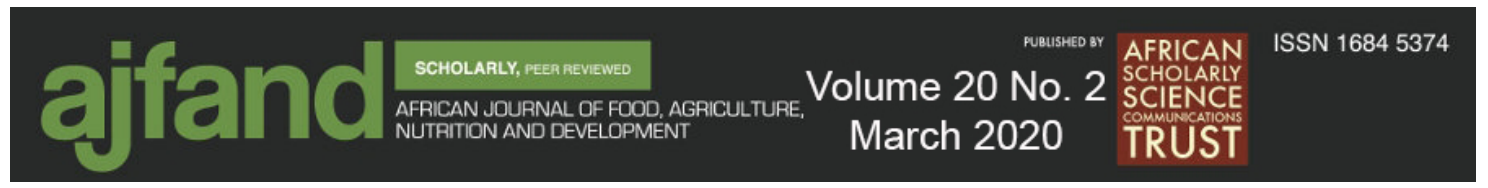

Table 2: Consumption and demand of different forms of fish

\begin{tabular}{lcccc}
\hline & Fresh Fish & Dried Fish & Frozen Fish & Smoked Fish \\
\hline Number of Consumers & $41(75.9 \%)$ & $39(72.2 \%)$ & $35(64.8 \%)$ & $29(53.7 \%)$ \\
Average monthly demand (kg) & 7.1 & 9.6 & 12.8 & 10.1 \\
\hline
\end{tabular}




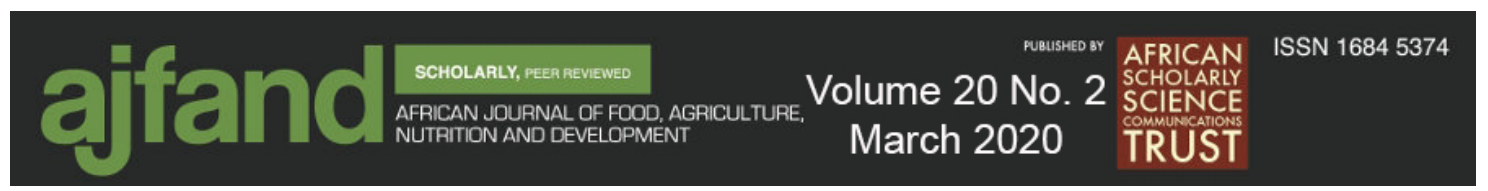

Table 3: Seemingly unrelated regression estimates of the determinants of demand of different forms of fish

\begin{tabular}{|c|c|c|c|c|}
\hline Variable/Form of Fish & Fresh Fish & Dried Fish & Frozen Fish & Smoked Fish \\
\hline \multirow[t]{2}{*}{ Age } & 0.045 & -0.383 & -0.331 & -0.383 \\
\hline & $(0.43)$ & $(-2.35)^{* *}$ & $(-1.63)$ & $(-3.37)^{* * *}$ \\
\hline \multirow[t]{2}{*}{ Gender } & 2.344 & -0.616 & 4.984 & -0.285 \\
\hline & $(2.06) * *$ & $(-0.35)$ & $(2.31)^{* *}$ & $(-0.24)$ \\
\hline \multirow[t]{2}{*}{ Marital Status } & -1.316 & 1.339 & -1.279 & -1.324 \\
\hline & $(-0.95)$ & $(0.63)$ & $(-0.49)$ & $(-0.90)$ \\
\hline \multirow[t]{2}{*}{ Household Size } & -0.024 & 0.792 & 0.545 & 0.693 \\
\hline & $(-0.11)$ & $(2.41)^{* *}$ & $(1.33)$ & $(3.02)^{* * *}$ \\
\hline \multirow[t]{2}{*}{ Income } & 0.00002 & 0.00002 & $8.64 \mathrm{e}-06$ & $4.51 \mathrm{e}-06$ \\
\hline & $(3.12)^{* * *}$ & $(2.04)^{* *}$ & $(0.38)$ & $(0.35)$ \\
\hline \multirow[t]{2}{*}{ Education } & -0.215 & 0.473 & 0.538 & 0.148 \\
\hline & $(-1.24)$ & $(1.78)^{*}$ & $(1.63)$ & $(0.80)$ \\
\hline \multirow[t]{2}{*}{ Price of fresh fish } & -0.003 & 0.0003 & 0.002 & 0.002 \\
\hline & $(-2.68)^{* * *}$ & $(2.20)^{* *}$ & $(1.28)$ & $(1.58)$ \\
\hline \multirow[t]{2}{*}{ Price of dried fish } & 0.0001 & -0.0004 & 0.0009 & -0.001 \\
\hline & $(2.40) * *$ & $(-3.20) * * *$ & $(0.55)$ & $(-1.06)$ \\
\hline \multirow[t]{2}{*}{ Price of frozen fish } & 0.0005 & 0.003 & 0.009 & 0.002 \\
\hline & $(0.26)$ & $(0.94)$ & $(2.42)^{* *}$ & $(1.83)^{*}$ \\
\hline \multirow[t]{2}{*}{ Price of smoked fish } & 0.001 & -0.002 & 0.0009 & 0.008 \\
\hline & $(0.64)$ & $(-0.82)$ & $(0.27)$ & $(4.55)^{* * *}$ \\
\hline \multirow[t]{2}{*}{ Constant } & 6.427 & 5.434 & -0.164 & 8.997 \\
\hline & $(2.01)^{* *}$ & $(1.11)$ & $(-0.03)$ & $(2.63)^{* * *}$ \\
\hline Chi square statistic & $20.88^{* *}$ & $20.87 * *$ & $31.21 * * *$ & $79.20 * * *$ \\
\hline R-squared & 0.28 & 0.28 & 0.37 & 0.59 \\
\hline Sample size (n) & 54 & 54 & 54 & 54 \\
\hline
\end{tabular}

Note: $* * *, * *$ and $*$ denote significant at $1 \%, 5 \%$ and $10 \%$, respectively

Values in parenthesis are z-values 


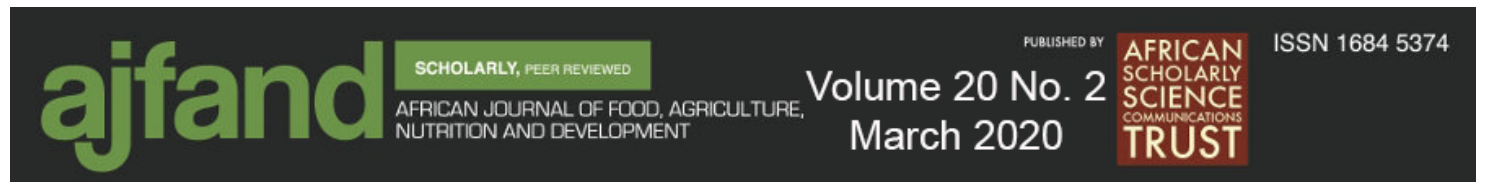

Table 4: Price and income elasticities of demand of different forms of fish

\begin{tabular}{lcc}
\hline Form of Fish/Elasticity & Own Price Elasticity & Income Elasticity \\
\hline Fresh Fish & -0.347 & 0.174 \\
Dried Fish & -0.030 & 0.129 \\
Frozen Fish & 0.318 & 0.040 \\
Smoked Fish & 0.341 & 0.028 \\
\hline
\end{tabular}




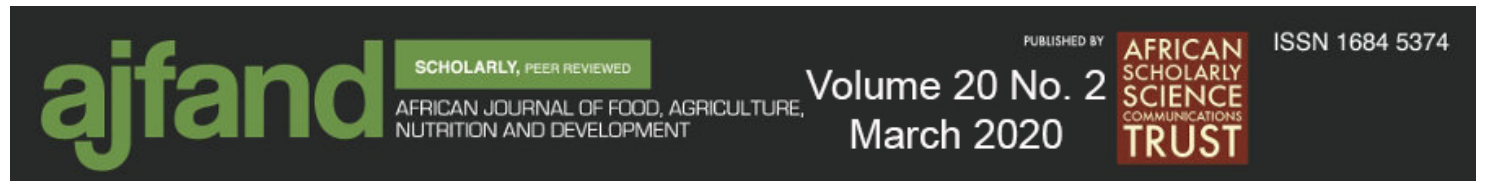

\section{REFERENCES}

1. High Level Panel of Experts. Sustainable fisheries and aquaculture for food security and nutrition. A report by the High Level Panel of Experts on Food Security and Nutrition. Committee on World Food Security, Rome (2014).

2. Lynch AJ and JR Macmillan The role of fish in a globally changing food system. In: Agroclimatology: Linking Agriculture to climate.

Doi:10.2134/agronmonogr60.2014.0059. (2017).

3. Millen B, Lichtenstein AH, Abrams S, Adams-Campbell L, Anderson C, Brenna JT, Campbell W, Clinton S, Foster G, Hu F, Nelson M, Neuhouser M, Pérez-Escamilla R, Siega-Riz AM and M Story Scientific Report of the 2015 Dietary Guidelines Advisory Committee of Disease Prevention and Health Promotion Washington, DC. (2015).

4. Nesheim MC and AL Yaktine Seafood choices: Balancing benefits and risks. The National Academic Press, Washington, DC. (2007).

5. FAO. The State of World Fisheries and Aquaculture: Meeting the Sustainable Development Goals. FAO, Rome. 2018.

6. Barange M, Bahri T, Beveridge MCM, Cochrane KL, Funge-Smith $\mathbf{S}$ and $\mathbf{F}$ Poulain Impacts of climate change on fisheries and aquaculture: synthesis of current knowledge, adaptation and mitigation options. FAO Fisheries and Aquaculture Technical Paper No. 627. Rome, FAO. 628 pp. (2018).

7. Falaye AE and A Jenyo-Oni Aquatic biodiversity and the implication in artisanal Fishing production. African Journal of Livestock Extension. (2009); 7:39-43.

8. Vannuccini S, Kavallari A, Bellu LG, Muller M and D Wisser Understanding the impact of climate change for fisheries and aquaculture: global and regional supply and demand trends and prospects. In M. Barange, T. Bahri, M.C.M. Beveridge, K.L. Cochrane, S. Funge-Smith and F. Poulain (eds.) Impacts of climate change on fisheries and aquaculture: synthesis of current knowledge, adaptation and mitigation options. FAO Fisheries and Aquaculture Technical Paper No. 627. Rome, FAO. Pp 41-57. (2018).

9. Tveterås S, Asche F, Bellamare MF, Smith MD, Guttormsen AG, Lem A, Lien $\mathbf{K}$ and S Vannuccini Fish is food - the FAO's Fish Price Index. PLoS ONE. 2012; 7(5): e36731.

10. FAO. The state of world fisheries and aquaculture 2016. Contributing to food security and nutrition for all. Rome. $200 \mathrm{pp}$. (also available at http://www.fao.org/3/a-i5555e.pdf. Accessed on December 12, 2019. (2016). 


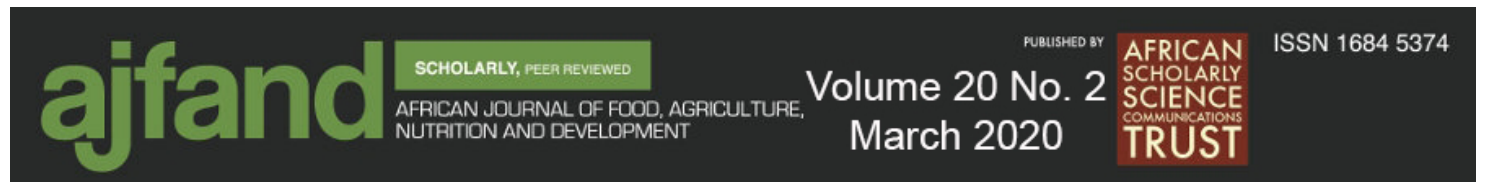

11. Amao JO, Oluwatayo IB and FK Osuntope Economics of Fish Demands in Lagos State, Nigeria. Journal of Human Ecology. 2006; 19(1): 25 - 30.

12. Veliu A, Gessese N, Ragasa C and C Okali Gender Analysis of Aquaculture Value Chain in Northeast Vietnam and Nigeria. Agriculture and Rural Development Discussion Paper 44. The World Bank. (2009).

13. Alexandratos $\mathbf{N}$ and J Bruinsma World Agriculture towards 2030/2050: The 2012 Revision. ESA Working Paper No. 12-03, Agricultural Development Economics Division Food and Agriculture Organization of the United Nations, Rome. 2012.

14. Alhassan EH, Boateng VF and C Ndaigo Smoked and frozen fish consumption and marketing channels in the Tamale metropolis of Ghana. Ghana Journal of Development Studies. (2012); 9(1): 21-28.

15. Dey MM, Garcia YT, Kumar P, Piumsombun S, Haque MS, Li L, Radam A, Senaratne A, Khiem NT and S Koeshedrajana Demand for fish in Asia: a crosscountry analysis. The Australian Journal of Agricultural and Resource Economics. (2008); 52: 321-338.

16. Idris S, Ochokwu IJ and MA Dambatta Fish Consumption Preference Among Residents of Hadejia Metropolis, Jigawa State, Nigeria. International Journal of Fisheries and Aquaculture Research. 2018; 4(2): 36-41.

17. Atin S, Taro $\mathbf{O}$ and $\mathbf{Y}$ Nobuyuki Changes in Fish Consumption Desire and Its Factors: A Comparison between the United Kingdom and Singapore. Foods. 2018; 7(7): 97.

18. Can MF, Gunlu A and HY Can Fish consumption preferences and factors influencing it. Food Science and Technology. (2015); 35(2): 339 - 346.

19. Burger J, Stephens WL, Boring CS, Kuklinski M, Gibbons JW and M Gochfeld Factors in exposure assessment: ethnic and socioeconomic differences in fishing and consumption of fish caught along the Savannah River. Risk Analysis. (1999); 19(3): 427-438.

20. Hicks D, Pivarnik $\mathbf{L}$ and $\mathbf{R}$ McDermott Consumer perceptions about seafood an internet survey. Journal of Foodservice. (2008); 19(4): 213-226.

21. Çolakoğlu FA, İşmen A, Özen Ö, Çakır F, Yığın Ç and HB Ormancı The evaluation of fish consumption in Çanakkale, E.U. Journal of Fisheries and Aquatic Sciences. (2006); 23(3):387-392.

22. Dalhatu M and AL Ala Analysis of fish demand in Sokoto Metropolis, Sokoto, Nigeria. Nigerian Journal of Basic and Applied Science. (2010); 18(2):154-159. 


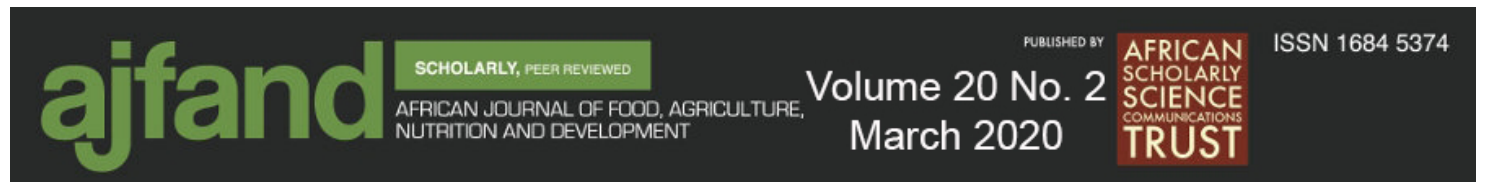

23. Debnath B, Biradar RS, Ananthan PS and SK Pandey Estimation of demand for different fish groups in Tripura. Agricultural Economics Research Review. (2012); 25(2):255-265.

24. Dey MM, Alam MF and FJ Paraguas A multistage budgeting approach to the analysis of demand for fish: An application to inland areas of Bangladesh. Marine Resource Economics. (2011); 26: 35-58.

25. Nankwenya B, Kaunda $\mathbf{E}$ and $\mathbf{S}$ Chimatiro The Demand for Fish Products in Malawi: An Almost Ideal Demand System Estimation. Journal of Economics and Sustainable Development. 2017; 8(16): 63 - 71. 